\title{
A STUDY ON GRIEVANCE HANDLING AND SATISFACTION LEVELS IN R I
}

\section{MANUFATURING COMPANY LIMITED}

\author{
S. POONGAVANAM ${ }^{1} \&$ NISHA $^{2}$ \\ ${ }^{I}$ Assistant. Professor, AMET Business School, AMET University, Chennai, Tamilnadu, India \\ ${ }^{2}$ Research Scholars, AMET Business School, AMET University, Chennai, Tamilnadu, India
}

\begin{abstract}
A grievance means any discontent or dissatisfaction whether expressed or not by the employees in the organization. Grievance may be valid or not, arising out of anything connected with the company than an employee thinks, believes or even feels, is unfair, unjust or inequitable. This article will focus on the grievance handling procedure followed and their level of satisfaction.
\end{abstract}

KEYWORDS: Grievance Handling, Level of Satisfaction \& Solution

Received: Oct 15, 2017; Accepted: Nov 06, 2017; Published: Nov 25, 2017; Paper Id.: IJMPERDDEC201748

\section{INTRODUCTION AND REVIEW}

Grievance is defined as any dissatisfaction regarding work and workplace filed by employee formally to his immediate supervisor (Rose, 2004). An organization establishes a grievance procedure to give an avenue to the employee to file his or her dissatisfactions. The establishment of grievance procedure is in line with the principle of "due process" (Mante-Meija \& Enid, 1991) which guarantees the application of procedural justice and ethical decision making in an organization. Besides the establishment of grievance procedure will resolve employees' dissatisfaction fairly, behaviour of personnel who handle grievance also brings effect to the employee's satisfaction on the result of grievance resolution. Managers will handle grievances referred to them base on their personality reference. Grievance handling mechanisms establish uniform conditions of employment with a view to avoid occurrence of industrial disputes. It lays down rules and norms for dealing with employees. As this study identifies the awareness among the employees towards grievance handling mechanism of study domain. It covers grievance-handling mechanism like open door policy, structured system, join committee, meeting, suggestion box, feedback.

\section{OBJECTIVES}

- To study the satisfaction levels of grievance handling

- $\quad$ To study the time limit of grievance handling

- To study the significant relationship between grievance handling and overall satisfaction

\section{RESEARCH METHODOLOGY}

This study is based on both primary and secondary data. The primary data have been collected from the employees of reliance life insurance company Limited. It is based on survey method. The structured questionnaire 
is used for finding out respondent's perception towards grievance handling mechanisms The researcher met the respondents in person to collect primary data. The questionnaire has two sections such as demographic profile and questionnaire information. The secondary data have been collected from various books, magazine, reports, and internet. Sample Size of this study is 300 . Non- probability sampling method has been used. Sample Design, the samples of 300 employees was selected by the convenient sampling technique.

\section{ANALYSIS AND DISCUSSIONS}

Table 1: Grievance Handling

\begin{tabular}{|l|c|c|}
\hline Level of Satisfaction & No's & Percentage \\
\hline Strongly agree & 17 & 5.67 \\
\hline Agree & 30 & 10.00 \\
\hline Neutral & 147 & 49.00 \\
\hline Disagree & 86 & 28.67 \\
\hline Strongly disagree & 20 & 6.66 \\
\hline & 300 & 100.00 \\
\hline
\end{tabular}

Inference: The above table shows $49 \%$ of population is of neutral, $28.67 \%$ is disagree, $10 \%$ is agree and strongly agree and strongly disagree percentage is very low.

Table 2: Method for Grievance Handling

\begin{tabular}{|l|c|c|}
\hline Level of Satisfaction & No's & Percentage \\
\hline Strongly agree & 147 & 49.00 \\
\hline Agree & 25 & 8.33 \\
\hline Neutral & 30 & 10.00 \\
\hline Disagree & 41 & 13.67 \\
\hline Strongly disagree & 57 & 19.00 \\
\hline & 300 & 100.00 \\
\hline
\end{tabular}

Inference: The above table shows $49 \%$ of total population is of strongly agree, $19 \%$ is strongly disagree, $13.67 \%$ is disagree, $10 \%$ is neutral and $8.33 \%$ of population is neutral.

Table 3: Time Limit of Grievance Solution

\begin{tabular}{|l|c|c|}
\hline Level of Satisfaction & No's & Percentage \\
\hline Strongly agree & 25 & 8.33 \\
\hline Agree & 40 & 13.34 \\
\hline Neutral & 165 & 55.00 \\
\hline Disagree & 60 & 20.00 \\
\hline Strongly disagree & 10 & 3.33 \\
\hline & 300 & 100.00 \\
\hline
\end{tabular}

Inference: The above table shows $55 \%$ of population is of neutral, $20 \%$ is disagree, $13.34 \%$ is agree, $8.33 \%$ is strongly agree and $3.33 \%$ is strongly disagree.

Table 4: Overall Satisfaction

\begin{tabular}{|l|c|c|}
\hline Level of Satisfaction & No's & Percentage \\
\hline Strongly agree & 98 & 32.67 \\
\hline Agree & 60 & 20.00 \\
\hline Neutral & 56 & 18.67 \\
\hline Disagree & 54 & 18.00 \\
\hline Strongly disagree & 32 & 10.66 \\
\hline & 300 & 100.00 \\
\hline
\end{tabular}


Inference: The above table shows $32.67 \%$ of the total population is of strongly agree, $20 \%$ is agree, neutral and disagree somewhat narrow difference and $10.66 \%$ is strongly disagree.

Table 5: Correlation Methods of handling grievances and overall satisfaction

\begin{tabular}{|l|l|c|c|c|}
\hline $\mathbf{X}$ & $\mathbf{Y}$ & Rank X & Rank Y & D \\
\hline 147 & 98 & 1 & 1 & 0 \\
\hline 25 & 60 & 5 & 2 & 3 \\
\hline 30 & 56 & 4 & 3 & 1 \\
\hline 48 & 45 & 3 & 3 & 0 \\
\hline 50 & 41 & 2 & 4 & 2 \\
\hline
\end{tabular}

Correlation value is 0.84

A correlation value close to 1 indicates association between the variables. Since the correlation value is 0.84 is nearer to 1 . It shows that there is perfect correlation.

\section{CONCLUSIONS}

One of the fast growing concepts in strategic human resource management is employee complaints and grievances handling. There is a need for all the organization to apply/ follow a suitable grievance handling mechanism to improve the productivity of the organization. If the employees are not satisfied with the grievance handling mechanism followed in the company it will create great problems in near future which cannot be solved immediately.

\section{REFERENCES}

1. Brubakk, B., and Wilkinson, A. (1996), Changing Roles of Middle Management: A Case Study of Bank Branch Management, Journal of Retail and Consumer Services, 3(1): 163-174.

2. Central Bank of Sri Lanka (1997), Foundation Laid for a Dynamic Financial System, The Economic Research Dept, Central Bank, Sri Lanka.

3. Davar, R.. S. (1992), Executive Motivation-A Behavioural Science Approach, in Davar, R. S. (Ed), The Human Side of Management, pp. 169-183, Universal Books, New Delhi.

4. M. A., and Warren, E. K. (1983), Managing the Middle, Human Resource Management, 22(1/2): 173-181.

5. Nilkant, V. and Ramnarayan, S. (1990), Managers in the Middle: A Case of Underdevelopment and Underutilisation, Vikalpa 15(2): 3-12.

6. Poval, M. (1985). Women in Banking, in Livy, B. L. (Ed), Management and People in Banking, pp. 325-340, The Chartered Institute of Bankers, London. 
